\title{
Endemic amphibians cornered in headwaters by trout invasion in a mountain range in Argentina
}

\author{
Daniela Miloch $^{1,2}$ (-) | Andrea Bonino ${ }^{1,2} \quad$ | Gerardo C. Leynaud ${ }^{1,2} \quad$ Julián N. Lescano ${ }^{1,2}$
}

${ }^{1}$ Facultad de Ciencias Exactas, Físicas, y Naturales, Centro de Zoología Aplicada, Universidad Nacional de Córdoba, Córdoba, Argentina

${ }^{2}$ Instituto de Diversidad y Ecología Animal, Consejo Nacional de Investigaciones

Científicas y Técnicas, Córdoba, Argentina

\section{Correspondence}

Julián N. Lescano, Universidad Nacional de Córdoba, Facultad de Ciencias Exactas, Físicas, y Naturales, Centro de Zoología Aplicada, Rondeau 798, Córdoba 5000, Argentina.

Email: lescanojul@gmail.com

Funding information

Rufford Foundation, Grant/Award Number: 8948-2

\begin{abstract}
1. The Sierras Pampeanas Centrales, one of the most important extra-Andean mountain systems of Argentina, harbour endemic and threatened amphibian species. In the past century, two alien predatory fish species (brook trout and rainbow trout) were introduced into rivers and streams of the area where amphibian species breed.

2. We hypothesized that the presence of trout would adversely affect the distribution of native amphibians in streams of the area. To test this hypothesis, the habitat requirements of trout and native amphibians were compared, and the effect of trout presence on amphibian occurrence was evaluated.

3. Transects $(n=126)$ were surveyed along rivers and streams in high-altitude grasslands of the area, and the occurrences of trout and amphibians and habitat variables were recorded.

4. The habitat requirements of each species were compared using multivariate methods. Generalized linear mixed models were used to evaluate whether the occurrence of amphibians depends on trout, habitat variables or both. The distribution of each species between streams orders was assessed.
\end{abstract}

5. The results showed that the presence of trout was the main factor conditioning the distribution of two endemic amphibian species (Boana cordobae and Odontophrynus achalensis) in basins of the study area.

6. This threat needs to be incorporated urgently into action plans to guide conservation efforts towards the management of trout populations.

\section{KEYWORDS}

alien species, amphibians, biodiversity, endangered species, fish, stream

\section{1 | INTRODUCTION}

Biological invasions are one of the main causes of the global decline of amphibians, the group of tetrapod vertebrates with the highest proportion of species under some category of threat (Hoffmann et al., 2010; Pimm et al., 2014; Stuart et al., 2004). The decline of amphibians caused by the introduction of alien species results from hybridization, the introduction of pathogens, competition and predation (Bucciarelli, Blaustein, Garcia, \& Kats, 2014; Collins \&
Storfer, 2003). In some regions, trout are invasive predatory fishes that have been widely distributed for recreational or commercial fishing purposes, with consequent severe changes to freshwater ecosystems (Leprieur, Beauchard, Blanchet, Oberdorff, \& Brosse, 2008; Ventura et al., 2017). The introduction of trout has devastating effects on aquatic ecosystems and native species, including amphibians (Dunham, Pilliod, \& Young, 2004; Kadye, Chakona, Marufu, \& Samukange, 2013; Kats \& Ferrer, 2003; Pilliod \& Peterson, 2001). The mechanisms underlying these impacts on amphibians include 
behavioural and physiological changes, as well as competition for shared food resources and predation, which can often lead to population extirpation of amphibians at both local and landscape levels (Bosch, Rincón, Boyero, \& Martínez-Solano, 2006; Brönmark \& Edenhamn, 1994; Collins, 2010; Knapp \& Matthews, 2000).

The introduction of trout in South America began in the early 1900s for sport and commercial fishing, and for aquaculture (Gubiani et al., 2018; Ventura et al., 2017). The main areas of trout population establishment were in high-altitude lakes and rivers, where the basins provided suitable habitat (Baigun \& Quiros, 1985; Gubiani et al., 2018). These high-elevation sites coincide with areas of particular biological importance because they harbour a great number of endemic species; hence, trout invasion affects native species that have high conservation value (Aigo et al., 2008; Buria, Albariño, Diaz Villanueva, Modenutti, \& Balseiro, 2007; Macchi \& Vigliano, 2014; Martín-Torrijos et al., 2016; Molineri, 2008). In Argentina, introduced trout are widespread in mountain-range water bodies. Although some authors have mentioned trout as a potential conservation problem for endemic or micro-endemic anurans in these systems (Brunetti, 2008; Cuello, Perotti, \& Iglesias, 2009; Vaira et al., 2012), to date evidence is scarce: only one study has reported changes in populations of two amphibian species resulting from the presence of trout (Velasco et al., 2018).

The Sierras Pampeanas Centrales (SPC) of Argentina is an extra-Andean mountain range that is important for conservation owing to its large number of endemic species (Cabido, Funes, Pucheta, Vendramini, \& Diaz, 1998; Lescano et al., 2015; Martínez, Arana, Oggero, \& Natale, 2016). High-altitude grasslands from the SPC (>1,600 $\mathrm{m}$ a.s.l.) contain four amphibian species that depend on lotic water bodies for breeding and tadpole development: Boana cordobae, Odontophrynus achalensis, Rhinella achalensis and Rhinella arenarum (Lescano et al., 2015; Verga, Leynaud, Lescano, \& Bellis, 2012). Except for $R$. arenarum, the remaining three species are endemic to the SPC and are categorized as Vulnerable or Threatened (Lavilla \& Di Tada, 2004; Lavilla, Di Tada, \& Reading, 2010). As well as the restricted distribution range, amphibians from this area face threats such as landscape modifications by human activities, and chytridiomycosis (Cingolani et al., 2014; Lescano et al., 2015; Lescano, Longo, \& Robledo, 2013). Rivers and streams in the high-altitude grasslands of the SPC were free from predator fishes until 1930 when two trout species were introduced: rainbow trout (Oncorhynchus mykiss, Salmonidae) and brook trout (Salvelinus fontinalis, Salmonidae) (Baigun \& Quiros, 1985; Bistoni \& Hued, 2002; Ferriz, Baigún, \& Dominino, 2010). At present, most rivers and streams of the SPC have been invaded by trout (Bistoni \& Hued, 2002; Ferriz et al., 2010); however, their impact on the biodiversity of the area has not yet been evaluated. There is an urgent need, therefore, to understand the impact of trout on the aquatic ecosystems of the SPC in order to establish management priorities for conservation purposes and to raise awareness among environmental authorities with jurisdiction in this extra-Andean mountain range of great importance for conservation. We hypothesized that the presence of trout would have a detrimental effect on the distribution of native amphibians in streams of the area. To test this hypothesis, the habitat requirements of trout and native amphibians were compared, and the effect of trout presence on amphibian occurrence was evaluated.

\section{2 | METHODS}

\subsection{Study area}

The study area covered $1,134 \mathrm{~km}^{2}$ in Sierras Grandes-Sierras de Comechingones, a mountain range within the SPC formation (central Argentina). The study was conducted between 1,600 and 2,800 $\mathrm{m}$ a.s.l., which coincides with the distribution range of the endemic amphibian species of the area (Lescano et al., 2015). The landscape of the region consists of valleys and ravines with different degrees of slope, rocky mountains and cliffs (Cabido \& Acosta, 1985). The vegetation is a mosaic of Polylepis australis forests, lawns and tussock grasses dominated by Poa stuckertii, Deyeuxia hieronymi and Festuca tucumanica. The average annual temperature in the area is $9.6^{\circ} \mathrm{C}$, with absolute maxima exceeding $30^{\circ} \mathrm{C}$ and absolute minima below $-10^{\circ} \mathrm{C}$ without frost-free months. The average annual rainfall is $870 \mathrm{~mm}$, concentrated between October and April (data obtained at $2200 \mathrm{~m}$ a. s.l. from Las Ensenadas meteorological station belonging to Instituto Nacional del Agua, Argentina).

A total of six basins were surveyed, some of which were located within Quebrada del Condorito National Park and some outside this protected area. Lotic water bodies from the study area are first- to fourth-order streams with a mean depth of $0.36 \mathrm{~m}$, ranging from 0.06 to $3.66 \mathrm{~m}$ (Ferriz et al., 2010 and data from the present study). The $\mathrm{pH}$ of the streams is slightly alkaline, with an average $\mathrm{pH}$ of 8.17 (range 6.5-9.13); water electrical conductivity varies between 19 and $67 \mu \mathrm{S} \mathrm{cm}{ }^{-1}$, with an average of $44.29 \mu \mathrm{S}$ $\mathrm{cm}^{-1}$ (Ferriz et al., 2010). Temperature and dissolved oxygen range between 6.9 and $17^{\circ} \mathrm{C}$ and between 7.7 and $10.2 \mathrm{mg} \mathrm{I}^{-1}$, respectively (Ferriz et al., 2010).

\section{2 | Study design}

Data were collected during two amphibian breeding seasons (August 2013 to March 2014 and August 2014 to March 2015). Sampling was conducted in 37 rivers and streams belonging to six basins. The selection of rivers and streams within these basins was based mainly on the presence and distribution of natural barriers (3-50 $\mathrm{m}$ high waterfalls) that establish a limit to trout invasion upstream. Thus, within each basin there were invaded sectors and sectors free from trout. In these water bodies, 126 of $150 \mathrm{~m}$ long transects were surveyed by two observers to record trout, amphibians and habitat data. Transects were at a distance of at least $200 \mathrm{~m}$ from each other and were located above and below the natural barriers identified. The most distant transects were at a straight-line distance of $54 \mathrm{~km}$ (coordinates of the northern transect, $31^{\circ} 14^{\prime} 44,6^{\prime \prime} \mathrm{S}, 64^{\circ} 52^{\prime} 35,3^{\prime \prime} \mathrm{W}$; coordinates of the southern 
transect, $\left.31^{\circ} 46^{\prime} 9,31^{\prime \prime} \mathrm{S}, 64^{\circ} 49^{\prime} 57,1^{\prime \prime} \mathrm{W}\right)$. Owing to the extent of the study area, the lack of roads and difficulties in gaining access for sampling streams, all the transects were sampled once.

\subsection{Amphibian and trout surveys}

Amphibian surveys were conducted in each transect during both day and night to evaluate the presence or absence of breeding adults, clutches or tadpoles. During the day, surveys included an active search of tadpoles with hand nets. At night, all transects were resampled using auditory surveys and Visual Encounter Surveys in search of adults of amphibian species (Crump \& Scott, 2001; Zimmerman, 2001). Trout presence/absence was recorded in each transect by two methods: visual assessment and rod angling. Rod angling has proved to be an effective and low-error method for detecting the presence of some trout species such as Salmo trutta and O. mykiss (Woodford \& McIntosh, 2013).

\section{4 | Habitat variables}

Local biotic and abiotic variables were recorded to characterize and compare the type of habitat used by amphibians and trout. In each transect, measurements were made of stream width $(\mathrm{m})$, average stream depth $(\mathrm{m})$, percentage cover of aquatic vegetation, canopy cover, herbaceous vegetation and type of substrate (rocky, loamy or sandy). All variables were measured in three $5 \mathrm{~m}$ stream stretches separated from each other by $75 \mathrm{~m}$ (one at the beginning of the transect, another in the middle and the last at the end of the transect). River width was obtained by measuring a shore-to-shore transversal river section with a tape measure at the centre of each $5 \mathrm{~m}$ stream stretch. Along each transversal river section, the average stream depth was obtained by taking three depth measurements. The percentage of aquatic vegetation cover and substrate composition were visually estimated in each $5 \mathrm{~m}$ stream stretch. Canopy cover and herbaceous vegetation were measured as the percentage of the shorelines of each $5 \mathrm{~m}$ stream stretch covered with trees and herbaceous vegetation. These variables were also visually estimated.

\section{5 | Data analysis}

The habitat requirements of trout and each amphibian species present in the system were compared via a multi-response permutation procedure (MRPP) test using PC-ORD version 6 software. This non-parametric method was used to determine whether there were significant differences in multiple habitat variables of transects used by amphibian species and trout. MRPP calculates a value $A=1-$ ( $\Delta$ observed/ $\Delta$ expected by chance). When there are significant statistical differences between groups $(P<0.05)$, the value of $A$ may range from 1 to $0: A=1$ (all variables are homogeneous within groups); $A=0$ (heterogeneity within groups is equal to that expected by chance); $A<0$ (heterogeneity within groups is greater than expected by chance) (McCune \& Grace, 2002). If $P>0.05$, there is no clustering and, therefore, no differences between groups.

The relationship between the occurrence of amphibian species and trout presence was analysed with $\mathrm{R}$ software ( $\mathrm{R}$ Development Core Team, 2019) using generalized linear mixed models (GLMMs) with glmmadmb function from the gImmADMB package with a binomial distribution and a logit linkage function (Fournier et al., 2012; Skaug, Fournier, Nielsen, Magnusson, \& Bolker, 2013). Models included the presence/absence of amphibian species as response variables, and trout presence/absence, surveyed season and habitat features as explanatory variables. A correlation analysis was performed between the independent variables to detect and exclude variables with redundant sources of variation. Herbaceous vegetation and sandy substrate were excluded following this exercise. Basins were included in the GLMMs as a random effect factor. The dredge function from the MuMIn package was used to build all possible combinations of variables, which were compared using the Akaike information criterion (AIC) (Mazerolle, 2006). Those with an AIC difference less than 2 were considered the best models and were used to build an average model.

The stream orders used by trout and amphibian species were also compared. For this a contingency table analysis was performed for the number of transects occupied by each species (amphibian species and trout) in different stream orders. To check the deviation of observed patterns from random, a Pearson $\chi^{2}$ test was performed using InfoStat software (Di Rienzo et al., 2018).

\section{3 | RESULTS}

Trout were present in $61 \%$ of the sampled transects $(n=77)$. Boana cordobae was found in $44 \%(n=56)$, O. achalensis in $27 \%(n=34)$, R. arenarum in $16 \%(n=20)$ and R. achalensis in $4 \%(n=5)$ of the surveyed transects. The mean and standard deviation of the habitat variables of the transects used by each species are reported in Table S1. MRPP showed no significant difference in habitat variables between invaded and non-invaded transects (Table S2). Occurrence patterns indicated that the presence of $B$. cordobae and O. achalensis decreased in the presence of trout (Figure 1). In contrast, the two Rhinella species were found both in invaded and non-invaded sites (Figure 1).

The presence of $B$. cordobae and $O$. achalensis was affected adversely by the presence of trout. The results of the average models showed that the presence of trout was the only significant variable that explained the occurrence of both amphibian species (Tables 1-4). No variable was significant in explaining the occurrence of $R$. arenarum (Tables 5 and 6). The construction of average models included a null model, which indicated that the presence of this species is not associated with any variable considered in the study (Table 5). The low occurrence recorded for R. achalensis (present only in five out of 126 transects) was a limitation for statistical analysis.

The use of streams of different order differed between species (Table 7). The two amphibian species for which occurrence was 


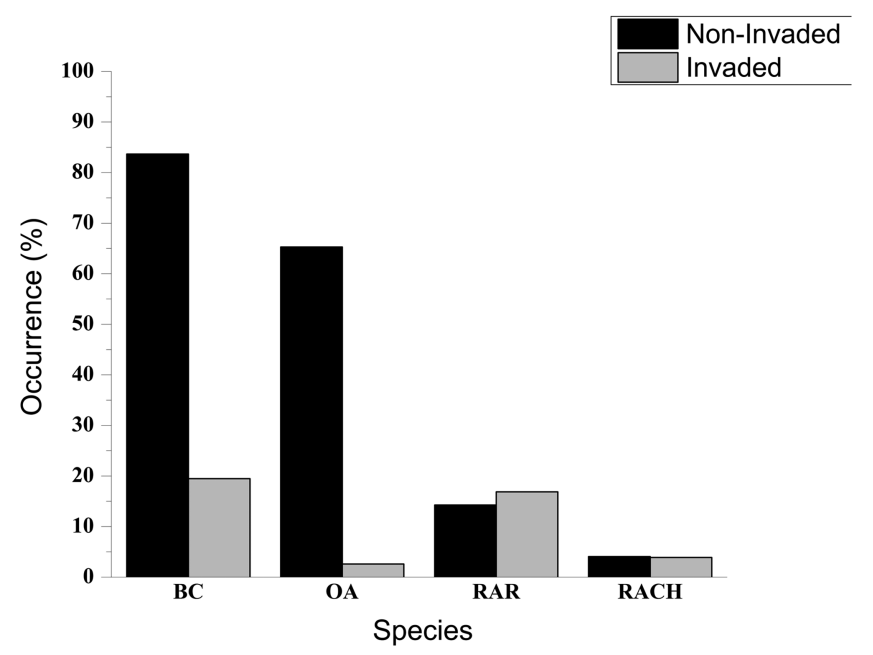

FIGURE 1 Occurrence patterns. Percentage of sites with presence of amphibian species in invaded (grey bars) and non-invaded (black bars) transects. BC, Boana cordobae; OA, Odontophrynus achalensis; RAR, Rhinella arenarum; RACH, Rhinella achalensis

influenced by the presence of trout (B. cordobae and $O$. achalensis) were more frequent in low-order streams, where trout are less frequent than expected from random (Tables 7 and S3). On the other hand, $R$. achalensis did not show a clear pattern in the use of streams of different orders, and $R$. arenarum was more frequent in fourth-order streams (Tables 7 and S3).

\section{4 | DISCUSSION}

According to the results, the amphibian and trout species studied inhabit streams with similar characteristics; nevertheless, there is low co-occurrence of $B$. cordobae and $O$. achalensis with trout in the sites surveyed. The main factor explaining the absence of both amphibian species in the stream surveyed was the presence of trout. As a consequence, the distribution of these species within streams is constrained by trout invasion, displacing them to low-order streams in headwaters (Table 7). As stated by Tiberti and von Hardenberg (2012), the patterns observed could result either from local population extirpations caused by trout predation or from amphibians avoiding invaded habitats. Although these hypotheses were not addressed in the present study, during the years of field surveys, personal observations have indicated several predation events by trout on adults and tadpoles of the two amphibian species. Co-occurrence of $B$. cordobae and trout was found in 15 surveyed sites, indicating that at least this species does not completely avoid invaded streams.

The effect of trout presence on $O$. achalensis was even more severe, as co-occurrence with trout was almost zero $(n=2)$, although habitat features in invaded transects are suitable for the species. This low co-occurrence could be related to the biology of tadpoles of the species. According to unpublished field data recorded by the authors, O. achalensis tadpoles are frequently associated with poorly vegetated sectors and with a greater proportion of rock in the substrate. According to Orizaola and Braña (2006), the use of aquatic vegetation

TABLE 1 Best generalized linear mixed models (GLMMs) explaining the occurrence of Boana cordobae

\begin{tabular}{|c|c|c|c|c|c|}
\hline Variables & d.f. & logLik & AIC & $\Delta$ AIC & $\omega \mathbf{i}$ \\
\hline Trout presence + Rocky substrate & 4 & -52.71 & 113.75 & 0.00 & 0.31 \\
\hline Trout presence + Rocky substrate + Canopy cover & 5 & -52.11 & 114.73 & 0.98 & 0.19 \\
\hline Trout presence + Depth + Rocky substrate & 5 & -52.34 & 115.18 & 1.44 & 0.15 \\
\hline Width + Trout presence + Rocky substrate & 5 & -52.48 & 115.46 & 1.72 & 0.13 \\
\hline Trout presence + Rocky substrate + Aquatic vegetation & 5 & -52.60 & 115.71 & 1.96 & 0.11 \\
\hline Trout presence + Loamy substrate + Rocky substrate & 5 & -52.61 & 115.72 & 1.98 & 0.11 \\
\hline
\end{tabular}

Abbreviations: d.f., degrees of freedom; logLik, Log-Likelihood-Ratio; AIC, Akaike's information criterion; $\Delta$ AIC, difference between the AIC value of the models and the AIC of the best model; $\omega$ i, the weight of Akaike.

TAB LE 2 Average model for the pattern of occurrence of B. cordobae

\begin{tabular}{|c|c|c|c|c|c|}
\hline Variables & Estimate & Standard error & Adjusted SE & Z-Value & $\operatorname{Pr}(>|Z|)$ \\
\hline (Intercept) & 3.43 & 1.03 & 1.04 & 3.29 & $0.0009^{*}$ \\
\hline Trout presence & -3.99 & 0.69 & 0.69 & 5.75 & $<2 \times 10^{-16^{*}}$ \\
\hline Rocky substrate & -0.02 & 0.01 & 0.01 & 1.96 & 0.0503 \\
\hline Canopy cover & 0.03 & 0.02 & 0.02 & 1.13 & 0.2578 \\
\hline Depth & 0.55 & 0.67 & 0.67 & 0.82 & 0.4129 \\
\hline Width & 0.08 & 0.11 & 0.11 & 0.66 & 0.5069 \\
\hline Aquatic vegetation & -0.01 & 0.01 & 0.01 & 0.45 & 0.6524 \\
\hline Loamy substrate & -0.01 & 0.02 & 0.01 & 0.43 & 0.6701 \\
\hline
\end{tabular}

*The statistically significant variables of the model. 
TABLE 3 Best GLMMs explaining the occurrence of Odontophrynus achalensis

\begin{tabular}{llllll} 
Variables & d.f. & logLik & AIC & Weight \\
\hline Trout presence + Canopy cover & 4 & -39.52 & 87.36 & 0.00 & 0.31 \\
\hline Trout presence & 3 & -40.91 & 88.01 & 0.65 & 0.22 \\
\hline Trout presence + Aquatic vegetation + Canopy cover & 5 & -39.00 & 88.49 & 1.13 & 0.17 \\
\hline Width + Trout presence + Canopy cover & 5 & -39.01 & 88.52 & 1.16 & 0.17 \\
\hline Trout presence + Season sampled + Canopy cover & 5 & -39.35 & 89.20 & 1.84 \\
\hline
\end{tabular}

TAB LE 4 Average model for the pattern of occurrence of O. achalensis

\begin{tabular}{|c|c|c|c|c|c|}
\hline Variables & Estimate & Standard error & Adjusted SE & Z-Value & $\operatorname{Pr}(>|Z|)$ \\
\hline (Intercept) & 0.45 & 0.48 & 0.49 & 0.93 & 0.354 \\
\hline Trout presence & -4.73 & 0.99 & 10.07 & 4.69 & $2.6 \times 10^{-6^{*}}$ \\
\hline Aquatic vegetation & 0.01 & 0.01 & 0.01 & 0.99 & 0.318 \\
\hline Width & 0.15 & 0.15 & 0.15 & 0.99 & 0.319 \\
\hline
\end{tabular}

*The statistically significant variables of the model.

TAB LE 5 Best GLMMs explaining the occurrence of Rhinella arenarum

\begin{tabular}{llllll} 
Variables & d.f. & logLik & AIC & Weight \\
\hline Null & 2 & -49.17 & 102.43 & 0.39 & 0.00 \\
\hline Width & 3 & -48.94 & 104.08 & 1.65 & 0.17 \\
\hline Trout presence & 3 & -49.08 & 104.36 & 1.92 & 0.15 \\
\hline Loamy substrate & 3 & -49.09 & 104.37 & 1.94 & 1.95 \\
\hline Sampling season & 3 & -49.09 & 104.39 & 0.15 \\
\hline
\end{tabular}

TAB LE 6 Average model for the pattern of occurrence of R. arenarum

\begin{tabular}{llllll} 
Variables & Estimate & Standard error & Adjusted SE & Z-Value & Pr(>|Z|) \\
\hline (Intercept) & -1.99 & 0.79 & 0.79 & 0.0161 \\
\hline Width & 0.07 & 0.11 & 0.11 & 0.67 & 0.5047 \\
\hline Trout presence & 0.24 & 0.58 & 0.58 & 0.41 & 0.6791 \\
Loamy substrate & -0.01 & 0.02 & 0.02 & 0.38 & 0.7023 \\
\hline Sampling season & 0.25 & 0.65 & 0.65 & 0.37 & 0.7084 \\
\hline
\end{tabular}

TABLE 7 Contingency table of the number of transects used by each species in each stream order

\begin{tabular}{|c|c|c|c|c|c|}
\hline Species & \multicolumn{4}{|c|}{ Stream order } & Tota \\
\hline Boana cordobae & 19 (34\%) & $26(47 \%)$ & $8(14 \%)$ & $3(5 \%)$ & 56 \\
\hline Odontophrynus achalensis & 15 (44\%) & 19 (56\%) & 0 & 0 & 34 \\
\hline Rhinella arenarum & $3(15 \%)$ & $8(40 \%)$ & $3(15 \%)$ & $6(30 \%)$ & 20 \\
\hline Rhinella achalensis & $1(20 \%)$ & $1(20 \%)$ & $2(40 \%)$ & $1(20 \%)$ & 5 \\
\hline
\end{tabular}

Note: $\chi^{2}=56.56$, d.f. $=12, P<0.0001$. 
as a refuge may be a key mechanism that allows amphibian species to survive at sites invaded by trout. Moreover, tadpoles of this species have a very long development time (more than a year). This trait combination could lead to the high exposure of $O$. achalensis tadpoles to predation by trout, explaining the extirpation of local populations from almost all of the invaded transects.

Taking into account these results, our observations on predation and the time since invasion, we conclude that the lack of these amphibian species in most invaded streams is the result of the depletion of populations by historic predation pressure (Pilliod \& Peterson, 2001). Constant invasion for almost a century may have prevented recruitment and the establishment and survival of larval and adult stages that eventually arrive at the sites from non-invaded streams. As found by Tiberti (2018) in lakes, $B$. cordobae and $O$. achalensis are currently restricted to noninvaded streams in the headwaters. At the same time, by forcing endemic amphibians to use low-order streams (that often are small and shallow), trout invasion may jeopardize the long-term persistence of local populations, as $O$. achalensis and B. cordobae have overwintering tadpoles and are therefore susceptible to drying and freezing (Pilliod \& Peterson, 2001). Overall, these strong negative associations between trout and amphibians agree with previous research conducted in lotic and lentic water bodies (Bosch et al., 2006; Ficetola et al., 2011; Hartel et al., 2007; Manenti \& Pennati, 2016; Orizaola \& Braña, 2006; Pilliod \& Peterson, 2001).

It is remarkable that the pattern of exclusion found for $O$. achalensis and B. cordobae was different from that observed for $R$. achalensis and $R$. arenarum (two species belonging to the family Bufonidae). In contrast to the prediction, the occurrence of $R$. arenarum did not respond to the presence of predators, and although $R$. achalensis was rare in the samples (which agrees with findings reported by Lescano, 2017), its occurrence in both invaded and noninvaded transects was quite similar. Within the Bufonidae there is a phylogenetic tendency towards the development of toxic substances in the skin as a defence mechanism against predation (Ficetola et al., 2011; Grasso, Coleman, \& Davidson, 2010; Jara \& Perotti, 2009; Regueira, Dávila, \& Hermida, 2016). Grasso et al. (2010) conducted palatability experiments and showed that $S$. fontinalis does not consume eggs, larvae or adults of Anaxyrus canorus (Bufonidae), even under conditions of extreme food shortages. Therefore, based on the results reported here, together with other available information, we suggest that trout introduced in the SPC do not have a direct detrimental effect on these two species owing to tadpole unpalatability. Further experimental studies will be needed to confirm this hypothesis.

The damaging effect of trout on B. cordobae and O. achalensis, two endemic amphibian species from the SPC, reveals part of a problem that may have even more complex consequences for the system. Based on previous studies (Matthews, Knapp, \& Pope, 2002), we suggest that amphibian extirpation caused by alien fishes could affect terrestrial amphibian-specialized predators such as the endemic snake Lygophis vanzolinii. Indeed, the extirpation of amphibian populations in the area may have indirect cascading effects modifying ecosystem functioning (e.g. nutrient cycles, primary production and ecological connection with surrounding terrestrial ecosystems; Eby, Roach, Crowder, \& Stanford, 2006). The existence and magnitude of such potential effects should be evaluated in the future, in order to provide a complete picture of the effect of alien aquatic fishes in the area.

The results of the present study have important implications for developing conservation action plans; these plans are important because the two affected species are endemic, and $\mathrm{O}$. achalensis is categorized as Vulnerable at national and international levels (Lavilla \& Di Tada, 2004). Moreover, besides trout invasion, these species are facing other threats such as chytridiomycosis (Lescano et al., 2013). Although some attempts to remove trout are under way to counteract invasion within Quebrada del Condorito National Park (pers. comm. from technical staff of the protected area), these actions are isolated and only cover two small segments in two streams. In contrast, trout invasion is widespread and extends beyond the protected area; thus, management actions should be consistent with the extent and severity of the problem. This implies the need for a joint management plan involving both the provincial environment authorities and the National Park administration. In addition, any management action on trout populations in the area should be accompanied by a robust public awareness campaign, given the popularity of these fish among anglers and local people who use them as a protein resource.

In our opinion, a stringent control plan prohibiting new trout introductions and fry commercialization, together with the control and monitoring of the distribution of currently established populations would represent an important starting point. The eradication of trout populations will result in a significant benefit not only for endemic amphibians in the area but also for the whole river ecosystems in this fragile environment, as found in other montane aquatic habitats (Bosch et al., 2019; Tiberti et al., 2019; Vredenburg, 2004).

\section{ACKNOWLEDGEMENTS}

We thank Francisco Molina, Andrés Issaly, Renzo Cresta, Belén Depetris, Mariano Lescano and Mauricio Akmentins for assistance in the field, and Jael Dominino for sharing information on trout distribution within Quebrada del Condorito National Park. Two anonymous reviewers improved the manuscript. We are very grateful to the Rufford Foundation for providing funding for this work. We also thank Secretaría de Ambiente y Cambio Climático from Córdoba Province and Administración de Parques Nacionales for allowing us to work in the study area.

\section{ORCID}

Daniela Miloch (D) https://orcid.org/0000-0001-7030-4155

\section{REFERENCES}

Aigo, J., Cussac, V., Peris, S., Ortubay, S., Gómez, S., López, H., ... Battini, M. (2008). Distribution of introduced and native fish in Patagonia (Argentina): Patterns and changes in fish assemblages. Reviews in Fish Biology and Fisheries, 18, 387-408. https://doi.org/10.1007/ s11160-007-9080-8

Baigun, C. R. M., \& Quiros, R. (1985). Introducción de peces exóticos en la República Argentina. Mar del Plata, Informe Técnico del Departamento de Aguas Continentales. 
Bistoni, M. A., \& Hued, A. C. (2002). Patterns of fish species richness in rivers of the central region of Argentina. Brazilian Journal of Biology, 62, 753-764. https://doi.org/10.1590/S1519-69842002000500004

Bosch, J., Bielby, J., Martin-Beyer, B., Rincón, P., Correa-Araneda, F., \& Boyero, L. (2019). Eradication of introduced fish allows successful recovery of a stream-dwelling amphibian. PLoS ONE, 14, e0216204. https://doi.org/10.1371/journal.pone.0216204

Bosch, J., Rincón, P. A., Boyero, L., \& Martínez-Solano, I. (2006). Effects of introduced salmonids on a montane population of Iberian frogs. Conservation Biology, 20, 180-189. https://doi.org/10.1111/j.15231739.2005.00296.x

Brönmark, C., \& Edenhamn, P. (1994). Does the presence of fish affect the distribution of tree frogs (Hyla arborea)? Conservation Biology, 8, 841-845. https://doi.org/10.1046/j.1523-1739.1994.08030841.x

Brunetti, A. (2008). Telmatobius oxycephalus (NCN). Predation. Herpetological Review, 39, 463.

Bucciarelli, G. M., Blaustein, A. R., Garcia, T. S., \& Kats, L. B. (2014). Invasion complexities: The diverse impacts of nonnative species on amphibians. Copeia, 2014, 611-632. https://doi.org/10.1643/ot14-014

Buria, L., Albariño, R., Diaz Villanueva, V., Modenutti, B., \& Balseiro, E. (2007). Impact of exotic rainbow trout on the benthic macroinvertebrate community from Andean-Patagonian headwater streams. Fundamental and Applied Limnology, 168, 145-154. https:// doi.org/10.1127/1863-9135/2007/0168-0145

Cabido, M., \& Acosta, A. (1985). Estudio fitosociológico de Polilepys australis Bitt. ('Tabaquillo') en las Sierras de Córdoba. Argentina. Documents Phytosociologiques, 9, 385-400. https://doi.org/10.1127/phyto/17/ 1989/569

Cabido, M., Funes, G., Pucheta, E., Vendramini, F., \& Diaz, S. (1998). A chorological analysis of the mountains from central Argentina. Is all what we call Sierra Chaco really Chaco? Candollea, 53, 321-331.

Cingolani, A. M., Vaieretti, M. V., Giorgis, M. A., Poca, M., Tecco, P. A., \& Gurvich, D. E. (2014). Can livestock grazing maintain landscape diversity and stability in an ecosystem that evolved with wild herbivores? Perspectives in Plant Ecology, Evolution and Systematics, 16, 143-153. https://doi.org/10.1016/j.ppees.2014.04.002

Collins, J. P. (2010). Amphibian decline and extinction: What we know and what we need to learn. Diseases of Aquatic Organisms, 92, 93-99. https://doi.org/10.3354/dao02307

Collins, J. P., \& Storfer, A. (2003). Global amphibian declines: Sorting the hypotheses. Diversity and Distributions, 9, 89-98. https://doi.org/10. 1046/j.1472-4642.2003.00012.x

Crump, M. L., \& Scott, N. J. (2001). Relevamientos por encuentros visuales. In W. R. Heyer, M. A. Donnelly, M. R. McDiarmid, L. C. Hayek, \& M. S. Foster (Eds.), Medición y monitoreo de la diversidad biológica: Métodos estandarizados para anfibios (pp. 80-87). Chubut: Smithsonian Institution Press \& Editorial Universitaria de la Patagonia.

Cuello, M. E., Perotti, M. G., \& Iglesias, G. J. (2009). Dramatic decline and range contraction of the endangered patagonian frog Atelognathus patagonicus (Anura, Leptodactylidae). Oryx, 43, 443-446. https://doi. org/10.1017/S0030605308000148

Di Rienzo, J. A., Casanoves, F., Balzarini, M. G., Gonzalez, L., Tablada, M., \& Robledo, C. W. (2018). InfoStat versión 2018. Grupo InfoStat, FCA, Universidad Nacional de Córdoba, Argentina. Retrieved from http:// www.infostat.com.ar

Dunham, J. B., Pilliod, D. S., \& Young, M. K. (2004). Assessing the consequences of nonnative trout in headwater ecosystems in Western North America. Fisheries, 29, 18-26. https://doi.org/10.1577/15488446(2004)29[18:ATCONT]2.0.CO;2

Eby, L. A., Roach, W. J., Crowder, L. B., \& Stanford, J. A. (2006). Effects of stocking-up freshwater food webs. Trends in Ecology \& Evolution, 21, 576-584. https://doi.org/10.1016/j.tree.2006.06.016

Ferriz, R. A., Baigún, C. R. M., \& Dominino, J. (2010). Distribution patterns and trophic characteristics of salmonids and native species inhabiting high altitude rivers of Pampa de Achala region, Argentina. Neotropical Ichthyology, 8, 851-860. https://doi.org/10.1590/S167962252010000400015

Ficetola, G. F., Siesa, M. E., Manenti, R., Bottoni, L., De Bernardi, F., \& Padoa-Schioppa, E. (2011). Early assessment of the impact of alien species: Differential consequences of an invasive crayfish on adult and larval amphibians. Diversity and Distributions, 17, 1141-1151. https:// doi.org/10.1111/j.1472-4642.2011.00797.x

Fournier, D. A., Skaug, H. J., Ancheta, J., Lanelli, J., Magnusson, A., Maunder, M. N., ... Sibert, J. (2012). AD Model Builder: Using automatic differentiation for statistical inference of highly parameterized complex nonlinear models. Optimization Methods and Software, 27, 233-249. https://doi.org/10.1080/10556788.2011.597854

Grasso, R. L., Coleman, R. M., \& Davidson, C. (2010). Palatability and antipredator response of Yosemite toads (Anaxyrus canorus) to nonnative brook trout (Salvelinus fontinalis) in the Sierra Nevada mountains of California. Copeia, 2010, 457-462. https://doi.org/10.1643/ch09-033

Gubiani, É. A., Ruaro, R., Ribeiro, V. R., Alegri Eichelberger, A. C., Bogoni, R. F., Dorigon Lira, A., ... da Graça, J. W. (2018). Non-native fish species in Neotropical freshwaters: How did they arrive, and where did they come from? Hydrobiologia, 817, 57-69. https://doi. org/10.1007/s10750-018-3617-9

Hartel, T., Nemes, S., Cogălniceanu, D., Öllerer, K., Schweiger, O., Moga, C.-I., \& Demeter, L. (2007). The effect of fish and aquatic habitat complexity on amphibians. Hydrobiologia, 583, 173-182. https://doi.org/10.1007/s10750-006-0490-8

Hoffmann, M., Hilton-Taylor, C., Angulo, A., Bohm, M., Brooks, T. M., Butchart, S. H. M., ... Stuart, S. N. (2010). The impact of conservation on the status of the world's vertebrates. Science, 330, 1503-1509. https://doi.org/10.1126/science.1194442

Jara, F. G., \& Perotti, M. G. (2009). Toad tadpole responses to predator risk: Ontogenetic change between constitutive and inducible defenses. Journal of Herpetology, 43, 82-88. https://doi.org/10.1670/07229R2.1

Kadye, W. T., Chakona, A., Marufu, L. T., \& Samukange, T. (2013). The impact of non-native rainbow trout within Afro-montane streams in eastern Zimbabwe. Hydrobiologia, 720, 75-88. https://doi.org/10. 1007/s10750-013-1624-4

Kats, L. B., \& Ferrer, R. P. (2003). Alien predators and amphibian declines: Review of two decades of science and the transition to conservation. Diversity and Distributions, 9, 99-110. https://doi.org/10.1046/j.14724642.2003.00013.x

Knapp, R. A., \& Matthews, K. R. (2000). Non-native mountain fish introductions and the decline of the yellow-legged frog from within protected areas. Conservation Biology, 14, 428-438. https://doi.org/ 10.1046/j.1523-1739.2000.99099.x

Lavilla, E., \& Di Tada, I. (2004). Odontophrynus achalensis. In IUCN 2019. The IUCN Red List of threatened species. Version 2019.2. Retrieved from http://www.iucnredlist.org/ [27 November 2019].

Lavilla, E., Di Tada, I., \& Reading, C. J. (2010). Rhinella achalensis. The IUCN Red List of threatened species. Version 2019.2. Retrieved from http:// www.iucnredlist.org/ [27 November 2019].

Leprieur, F., Beauchard, O., Blanchet, S., Oberdorff, T., \& Brosse, S. (2008). Fish invasions in the world's river systems: When natural processes are blurred by human activities. PLoS Biology, 6, e28. https://doi.org/ 10.1371/journal.pbio.0060028

Lescano, J. N. (2017). Rhinella achalensis en declinación? Observaciones sobre el estado actual de las poblaciones del Sapo de Achala. Cuadernos de Herpetología, 32, 15-32. https://doi.org/10.31017/cdh. 2018.(2017-18)

Lescano, J. N., Longo, S., \& Robledo, G. (2013). Chytridiomycosis in endemic amphibians of the mountain tops of the Córdoba and San Luis ranges, Argentina. Diseases of Aquatic Organisms, 102, 249-254. https://doi.org/10.3354/dao02551 
Lescano, J. N., Nori, J., Verga, E., Robino, F., Bonino, A., Miloch, D., .. Leynaud, G. C. (2015). Anfibios de las Sierras Pampeanas Centrales de Argentina: Diversidad y distribución altitudinal. Cuadernos de Herpetología, 29, 103-115.

Macchi, P. J., \& Vigliano, P. H. (2014). Salmonid introduction in Patagonia: The ghost of past, present and future management. Ecología Austral, 24, 162-172.

Manenti, R., \& Pennati, R. (2016). Environmental factors associated with amphibian breeding in streams and springs: Effects of habitat and fish occurrence. Amphibia-Reptilia, 37, 237-242. https://doi.org/10.1163/ 15685381-00003040

Martínez, G. A., Arana, M. D., Oggero, A. J., \& Natale, E. S. (2016). Biogeographical relationships and new regionalisation of high-altitude grasslands and woodlands of the central Pampean Ranges (Argentina), based on vascular plants and vertebrates. Australian Systematic Botany, 29, 473-488. https://doi.org/10.1071/SB16046

Martín-Torrijos, L., Sandoval-Sierra, J. V., Muñoz, J., DiéguezUribeondo, J., Bosch, J., \& Guayasamin, J. M. (2016). Rainbow trout (Oncorhynchus mykiss) threaten Andean amphibians. Neotropical Biodiversity, 2, 26-36. https://doi.org/10.1080/23766808.2016.1151133

Matthews, K. R., Knapp, R. A., \& Pope, K. L. (2002). Garter snake distributions in high-elevation aquatic ecosystems: Is there a link with declining amphibian populations and nonnative trout introductions? Journal of Herpetology, 36, 16-22. https://doi.org/10.1670/0022-1511(2002) 036[0016:GSDIHE]2.0.CO;2

Mazerolle, M. J. (2006). Improving data analysis in herpetology: Using Akaike's Information Criterion (AIC) to assess the strength of biological hypotheses. Amphibia-Reptilia, 27, 169-180. https://doi.org/10. $1163 / 156853806777239922$

McCune, B., \& Grace, J. (2002). MRPP (multi-response permutation procedures) and related techniques. In Analysis of Ecological Communities (pp. 188-197). Gleneden Beach, OR: MjM Software Design.

Molineri, C. (2008). Impact of rainbow trout on aquatic invertebrate communities in subtropical mountain streams of northwest Argentina. Ecología Austral, 18, 101-117.

Orizaola, G., \& Braña, F. (2006). Effect of salmonid introduction and other environmental characteristics on amphibian distribution and abundance in mountain lakes of northern Spain. Animal Conservation, 9, 171-178. https://doi.org/10.1111/j.1469-1795.2006.00023.x

Pilliod, D. S., \& Peterson, C. R. (2001). Local and landscape effects of introduced trout on amphibians in historically fishless watersheds. Ecosystems, 4, 322-333. https://doi.org/10.1007/s10021-001-0014-3

Pimm, S. L., Jenkins, C. N., Abell, R., Brooks, T. M., Gittleman, J. L., Joppa, L. N., ... Sexton, J. O. (2014). The biodiversity of species and their rates of extinction, distribution, and protection. Science, 344 1-10. https://doi.org/10.1126/science.1246752

R Development Core Team (2019). R: A language and environment for statistical computing. R Foundation for Statistical Computing, Vienna. Retrieved from https://www.R-project.org/

Regueira, E., Dávila, C., \& Hermida, G. N. (2016). Morphological changes in skin glands during development in Rhinella arenarum (Anura: Bufonidae). The Anatomical Record, 299, 141-156. https://doi.org/10. 1002/ar.23284

Skaug, H., Fournier, D., Nielsen, A., Magnusson, A., \& Bolker, B. (2013). Generalized linear mixed models using AD Model Builder. R Package Version 0.7.7. Retrieved from http://glmmadmb.r-forge.r-project.org/

Stuart, S. N., Chanson, J. S., Cox, N. A., Young, B. E., Rodrigues, A. S. L., Fischman, D. L., \& Waller, R. W. (2004). Status and trends of amphibian declines and extinctions worldwide. Science, 306, 1783-1786. https://doi.org/10.1126/science.1103538

Tiberti, R. (2018). Can satellite ponds buffer the impact of introduced fish on newts in a mountain pond network? Aquatic Conservation: Marine and Freshwater Ecosystems, 28, 457-465. https://doi.org/10.1002/ aqc. 2858

Tiberti, R., Bogliani, G., Brighenti, S., lacobuzio, R., Liautaud, K., Rolla, M., ... Bassano, B. (2019). Recovery of high mountain Alpine lakes after the eradication of introduced brook trout Salvelinus fontinalis using non-chemical methods. Biological Invasions, 21, 875-894. https://doi. org/10.1007/s10530-018-1867-0

Tiberti, R., \& von Hardenberg, A. (2012). Impact of introduced fish on common frog (Rana temporaria). Amphibia-Reptilia, 33, 303-307. https://doi.org/10.1163/156853812X634044

Vaira, M., Akmentins, M., Attademo, M., Baldo, D., Barrasso, D. Barrionuevo, S., ... Zaracho, V. (2012). Categorización del estado de conservación de los anfibios de la República Argentina. Cuadernos de Herpetología, 26, 131-159.

Velasco, M. A., Berkunsky, I., Simoy, M. V., Quiroga, S., Bucciarelli, G., Kats, L., \& Kacoliris, F. P. (2018). The rainbow trout is affecting the occupancy of native amphibians in Patagonia. Hydrobiologia, 817, 447-455. https://doi.org/10.1007/s10750-017-3450-6

Ventura, M., Tiberti, R., Buchaca, T., Buñay, D., Sabás, I., \& Miró, A. (2017). Why should we preserve fishless high mountain lakes? In J. Catatan, J. M. Ninot, \& M. M. Aniz (Eds.), High mountain conservation in a changing world (pp. 181-205). Cham: Springer.

Verga, E. G., Leynaud, G. C., Lescano, J. N., \& Bellis, L. M. (2012). Is livestock grazing compatible with amphibian diversity in the High Mountains of Córdoba, Argentina? European Journal of Wildlife Research, 58, 823-832. https://doi.org/10.1007/s10344-012-0630-6

Vredenburg, V. T. (2004). Reversing introduced species effects: Experimental removal of introduced fish leads to rapid recovery of a declining frog. Proceedings of the National Academy of Sciences of the United States of America, 101, 7646-7650. https://doi.org/10.1073/ pnas.0402321101

Woodford, D. J., \& Mclntosh, A. R. (2013). Effects of introduced trout predation on non-diadromous galaxiid fish populations across invaded riverscapes. Science for Conservation 320. (pp. 1-23). Wellington, New Zeland: Department of Conservation.

Zimmerman, B. L. (2001). Transectas de bandas auditivas. In W. R. Heyer, M. A. Donnelly, M. R. McDiarmid, L. C. Hayek, \& M. S. Foster (Eds.), Medición y monitoreo de la diversidad biológica: Métodos estandarizados para anfibios (pp. 87-93). Chubut: Smithsonian Institution Press \& Editorial Universitaria de la Patagonia.

\section{SUPPORTING INFORMATION}

Additional supporting information may be found online in the Supporting Information section at the end of this article.

How to cite this article: Miloch D, Bonino A, Leynaud GC, Lescano JN. Endemic amphibians cornered in headwaters by trout invasion in a mountain range in Argentina. Aquatic Conserv: Mar Freshw Ecosyst. 2020;1-8. https://doi.org/10. 1002/aqc.3441 